\title{
KONTRIBUSI SELF EFFICACY DAN KECERDASAN EMOSIONAL TERHADAP KINERJA GURU BK DI SMP KOTA PEKANBARU
}

\author{
Hera Yuliarnita ${ }^{1)}$ \\ Daeng Ayub Natuna ${ }^{2)}$ \\ Azhar 3) \\ ${ }^{1)}$ SMP Negeri 21 Pekanbaru \\ 2) Lecturer of Education Management Study Programme PPS University of Riau \\ 3) Lecturer of Education Management Study Programme PPs University of Riau \\ Email: hera.yuliarnita@yahoo.com
}

\begin{abstract}
This research is aimed to evaluate and to analyze the self efficacy contribution and emotional intelegence towards counseling teachers' performance. The population of this research is the teachers of state Junior High School in Pekanbaru.as calculated about 82 teachers and all are estimated accurately. The types of data used in this research are primary and secondary data gotten from teachers by using questioner. The techniques of data analyzing system used in this research are descriptive statistic and inferential statistic analysis. The collecting data system of descriptive statistic analysis in this research used Microsoft excel program and SPSS version 23 for windows. The result of this research showed that there is a significant contribution between self efficacy variable (X1) and emotional intelligence (X2) towords counseling teachers' performance $(Y)$ in Junior High School Pekanbaru
\end{abstract}

Keywords: Self Efficacy; Emotional Intelegence; Teachers Performance

\begin{abstract}
ABSTRAK
Penelitian ini bertujuan untuk menguji dan menganalisis kontribusi self efficacy dan kecerdasan emosional terhadap kinerja guru BK. Populasi dari penelitian ini adalah Guru SMP Negeri Kota Pekanbaru yang berjumlah 82 orang dan semua diteliti. Jenis data dari penelitian ini adalah data primer dan data skunder untuk yang diperoleh dari guru dengan menggunakan kuisioner. Teknik analisis data yang digunakan dalam penelitian ini adalah analisis statistik deskriptif dan analisis statistik inferensial. Pengolahan data untuk analisis statistik deskriptif dalam penelitian ini menggunakan program Microsoft Excel dan SPSS versi 23 for Windows. Hasil penelitian ini menunjukkan bahwa adanya kontribusi yang signifikan antara variabel self efficacy $\left(\mathrm{X}_{1}\right)$ dan kecerdasan emosional $\left(\mathrm{X}_{2}\right)$ terhadap kinerja guru BK (Y) di SMP kota Pekanbaru
\end{abstract}

Kata Kunci: Self Efficacy; Kecerdasan Emosional; Kinerja Guru BK 


\section{PENDAHULUAN}

Di dalam Undang-Undang Nomor 20 tahun 2003 pasal 1 ayat 1 tentang Sistem Pendidikan Nasional mengamanatkan bahwa pendidikan merupakan usaha sadar dan terencana untuk mewujudkan suasana belajar dan proses pembelajaran agar peserta didik secara aktif mengembangkan potensi dirinya untuk memiliki kekuatan spiritual keagamaan, pengendalian diri, kepribadian, kecerdasan, akhlak mulia serta ketrampilan yang dimiliki dirinya, masyarakat, bangsa, dan negara.

Daryanto \& Farid (2015: 123) menjelaskan bahwa guru bimbingan konseling atau konselor harus menunjukkan kinerjanya secara profesional yang meliputi : (a) menampilkan diri sebagai konselor dengan program kerja yang jelas dan siap untuk dilaksanakan, (b) mempertahankan sikap profesional, (c) tanggung jawab untuk memahami perannya sebagai konselor profesional dan menterjemahkannya kedalam kegiatan nyata, (d) bekerja dengan efektif dan memahami tanggung jawabnya, (e) memahami dan mengembangkan kompetensinya.

Fenomena dilapangan ditemukan masih ada guru BK yang belum memiliki Self Efficacy yang baik, seperti belum semua guru BK dapat menyelesaikan tugas tertentu, Selain itu kinerja guru BK dapat ditentukan pula oleh kecerdasan emosionalnya. Fenomena dilapangan masih terdapat guru BK yang belum mengenal emosi diri, masih ada guru BK yang belum sepenuhnya dapat mengelola emosi dengan baik, belum dapat memotivasi diri, masih adanya guru BK yang belum mengenal emosi orang lain, serta belum maksimalnya guru BK dalam membina hubungan, baik dengan rekan sejawat, orang tua, serta stake holder lainnya. Seterusnya kinerja guru BK ditentukan oleh banyak indikator seperti kualitas dan kuantitas hasil kerja, inisiatif dan kerjasama, fenomena bahwa sebagian guru BK kualitas hasil kerjanya belum baik, seterusnya kuantitas hasil kerja merekapun belum memuaskan dan sebagian guru BK masih kurang inisiatif menjalankan tugas, serta sesama guru BK dan guru lainnya ada diantara guru BK yang belum dapat bekerja sama dengan baik.

\section{Rumusan Masalah}

Berdasarkan latar belakang yang telah dikemukakan maka rumusan masalah pada penelitian ini adalah:

1. Apakah terdapat Kontribusi positif antara Self Efficacy terhadap Kinerja guru BK SMP Negeri kota Pekanbaru?

2. Apakah terdapat Kontribusi positif antara Kecerdasan Emosional terhadap terhadap Kinerja guru BK SMP Negeri kota Pekanbaru?

3. Apakah terdapat Kontribusi positif antara Self Efficacy dan Kecerdasan Emosional secara bersama-sama terhadap Kinerja guru BK SMP Negeri kota Pekanbaru?

\section{Tujuan Penelitian}

Tujuan dari penelitian ini adalah

1. Untuk menganalisis Kontribusi antara Self Efficacy terhadap Kinerja guru BK SMP Negeri kota Pekanbaru.

2. Untuk menganalisis Kontribusi antara Kecerdasan Emosional terhadap terhadap Kinerja guru BK SMP Negeri kota Pekanbaru.

3. Untuk menganalisis Kontribusi antara Self Efficacy dan Kecerdasan Emosional secara bersama-sama terhadap Kinerja guru BK SMP Negeri kota Pekanbaru.

\section{Manfaat Penelitian}

1. Manfaat Teoritis 
Penelitian ini diharapkan dapat menambah wawasan ilmu pengetahuan sebagai salah satu referensi dan tindak lanjut bagi yang ingin mengembangkan kajian dalam meningkatkan Kinerja guru BK.

\section{Manfaat Praktis}

Dengan adanya penelitian ini diharapkan kepada para pembuat kebijakan pendidikan dapat digunakan untuk menyusun program dalam meningkatkan Kinerja guru BK, meningkkatkan Self Efficacy guru BK, dan meningkatkan Kecerdasan Emosional pada masa yang akan datang sehingga menghasilkan kualitas dan prokduktifitas kerja secara efektif dan efisien. Sebagai bahan masukan bagi pihak sekolah khususnya guru dan kepala-kepala sekolah bahwa Self Efficacy, dan Kecerdasan Emosional dapat menentukan baik dan buruknya Kinerja guru BK..

\section{A. KAJIAN PUSTAKA}

\section{Kinerja Guru}

Menurut Mariana Kristiyanti (2012:105), kinerja (performance) adalah Suatu gambaran tentang tingkat pencapaian pelaksanaan suatu kegiatan dalam mewujudkan sasaran, tujuan, misi dan visi organisasi yang tertuang dalam Perencanaan Strategis (strategic planning) suatu organisasi.

Peraturan Menteri Pendidikan Nasional Dalam Peraturan Menteri Negara Pendayagunaan Aparatur Negara dan Reformasi Birokrasi Nomor 16 Tahun 2009 tentang jabatan Fungsional guru dan angka kreditnya pada Bab I pasal 1 ayat 1 dan 4 menyebutkan bahwa: Jabatan fungsional guru adalah jabatan yang mempunyai ruang lingkup tugas, tanggung jawab dan wewenang untuk melakukan kegiatan mendidik, mengajar, membimbing, mengarahkan, melatih, menilai dan mengevaluasi peserta didik serta melakukan kegiatan bimbingan yaitu kegiatan guru dalam menyusun rencana bimbingan, melaksanakan bimbingan, mengevaluasi proses dan hasilbimbingan serta melakukan perbaikan tindak lanjut bimbingan dengan memanfaatkan hasil evaluasi.

Jadi dari uraian yang sudah dijabarkan dapat diartikan bahwa kinerja guru BK merupakan sebuah hasil kerja yang dicapai oleh guru BK dengan melaksanakan program yang dibuat untuk mencapai sasaran yang diinginkan dengan penuh tanggung jawab.

\section{Indikator Kinerja Guru}

Menurut Suharsaputra (2010:147) bahwa pengertian kinerja menunjuk pada ciri-ciri atau indikator sebagai berikut:

a) Mengukur Kualitas Hasil Kerja

b) Mengukur Kuantitas Hasil Kerja

c) Mempunyai Inisiatif

d) Membina Kerjasama yang baik sesame TIM

\section{Faktor-Faktor yang Mempengaruhi Kinerja Guru}

Ada beberapa faktor-faktor yang mempengaruhi kinerja menurut Dari hasil penelitian yang dilakukan oleh Hanung Sudibyo (2018:20) memperoleh hasil simpulan, Faktor yang mempengaruhi kinerja guru BK yaitu: (a) kepemimpinan dari kebijakan pusat, dinas pendidikan dan kepala sekolah maupun organisasi, (b) motivasi guru dari diri sendiri maupun dari luar, (c) kompetensi guru, (d) pendidikan dan pelatihan.

Sedangkan Gibson dalam Suharsaputra (2010:147) bahwa kinerja seseorang dalam menjalankan peran dan fungsinya dipengaruhi oleh: Variabel 
Individu, Variabel Organisasi, dan Variabel Psikologis. dapat menggambarkan bahwa faktor-faktor yang mempengaruhi kinerja seseorang adalah faktor individu dengan karakteristik psikologisnya yang khas, dan faktor organisasi berinteraksi dalam suatu proses yang dapat mewujudkan suatu kualitas kerja dalam suatu lingkungan kerja seseorang tersebut.

\section{Self-efficacy}

Menurut Jeanne Ellis Ormrod (2008:20) menyatakan bahwa self efficacy adalah keyakinan bahwa seseorang mampu menjalankan perilaku tertentu atau mencapai tujuan tertentu.

Gerson Salomo Kolondam (2018:5) Self efficacy merupakan keyakinan seorang individu terhadap kemampuan yang dimilkinya dalam mengatur dan melaksanakan tindakan atau tugas untuk mencapai suatu tujuan. Woolfolk dalam Gerson Salomo kolondam (2018:5) menjelaskan secara umum self efficacy adalah penilaian seseorang terhadap dirinya sendiri atau tingkat keyakinan tentang seberapa besar kemampuannya dalam mengerjakan suatu tugas yang dilaksanakannya yang bertujuan untuk mencapai hasil tertentu yang akan dicapainya.

Berdasarkan uraian tersebut dapat disimpulkan bahwa self efficacy atau efikasi diri merupakan keyakinan pada diri sendiri untuk menghadapi dan menyelesaikan permasalahan dan tugas yang akan dihadapi, serta mampu melakukan control pada diri sendiri sehingga dapat mencapai tujuan yang ingin dicapai.

\section{Indikator Self Efficacy}

Indikator Self Efficacy tersebut sebagai berikut:

1. Menetapkan target ketuntasan tugas
2. Menumbuhkan motivasi diri dalam menyelesaikan tugas

3. Berusaha keras, gigih, dan tekun

4. Bertahan serta Bangkit menghadapi hambatan dan kesulitan

5. Menyelesaikan tugas tidak terbatas

\section{Kecerdasan Emosional}

Robert K. Cooper dan Sawaf dalam Hanik Rosidah (2016:14) Menjelaskan bahwa Kecerdasan emosional adalah kemampuan merasakan, memahami secara efektif menerapkan daya dan kepekaan emosi sebagai sumber energi, informasi, koneksi dan pengaruh yang manusiawi. Sedangkan menurut Bar-On dalam Lies Ariana (2014:23) menyatakan bahwa kecerdasan emosional adalah serangkaian kemampuan, kompetensi dan kecakapan non kognitif, yang mempengaruhi kemampuan seseorang untuk berhasil mengatasi tuntutan dan tekanan lingkungan. Dari definisi yang telah dikemukan tentang kecerdasan emosional lebih menekankan pada hasil yang didapat oleh individu jika menggunakan kemampuan emosionalnya secara optimal.

Selain itu Menurut Goleman, dalam Pebri Romadhoni (2017: 20) Emotional Intelligence adalah kemampuan seseorang mengatur menjaga keselarasan emosi dan pengungkapannya (theappropriateness of emotion and itsexpression) melalui keterampilan kesadaran diri, pengendalian diri, motivasi diri, empati dan keterampilan social.

Sedangkan menurut Milatus Sholiha dkk (2017:82) menjelaskan bahwa kecerdasan emosional adalah kemampuan seseorang dalam menggunakan atau mengelola emosi baik pada diri sendiri maupun ketika berhadapan dengan orang lain, dan menggunakannya secara efektif untuk 
memotivasi diri dan bertahan pada tekanan, serta mengendalikan diri untuk mencapai hubungan yang produktif.

Dapat disimpulkan bahwa Emotional Intelligence (kecerdasan emosional) merupakan kemampuan seseorang untuk menyadari, mengamati dan memahami emosi dan perasaan diri sendiri maupun orang lain, dan menggunakannya sebagai pertimbangan untuk bertindak. Dalam penelitian ini yang dimaksud dengan Emotional Intelligence adalah kemampuan dari guru Bimbingan dan Konseling (BK) untuk mengenali emosi diri, mengelola emosi diri, memotivasi diri sendiri, mengenali emosi orang lain (empati) dan kemampuan untuk membina hubungan (kerjasama) dengan orang lain.

\section{Indikator Kecerdasan Emosional} Indikator dari Kecerdasan Emosional tersebut sebagai berikut:

1. Mengenal emosi diri.

2. Mengelola emosi

3. Memotivasi diri sendiri

4. Mengenali emosi orang lain (Empati)

5. Membina hubungan

\section{Kerangka Penelitian}

\section{Kontribusi self efficacy terhadap Kinerja Guru BK}

Fadiarni Widyaning Putri

(2015:10) bahwa semakin tinggi efikasi diri seseorang, semakin besar pula kepercayaan dari orang tersebut terhadap kesanggupannya untuk berhasil dalam mencapai tujuan.

Dewi Herawaty (2016:80) juga menyatakan bahwa semakin tinggi self efficacy yang dimiliki seseorang, akan semakin baik kegiatan yang dilakukannya dalam berbagai tugas yang dilaksanakannya dan mempunyai tanggungjawab.
Self effikasi merupakan keyakinan diri seseorang untuk dapat mencapai tujuan tertentu. Self efficacy merupakan karakteristik yang melekat pada diri seseorang yang dapat mempengaruhi pilihan dan tindakan terhadap indvidu tersebut. Individu yang memiliki keyakinan diri untuk dapat mencapai tujuan yang tinggi, individu tersebut akan dapat untuk menyelesikan tugasnya dengan baik. Begitu juga sebaliknnya. Dengan demikian individu yang memiliki keyakinan untuk dapat menyelesaikan tugas yang diberikan kepadanya maka individu tersebut menghasilkan prestasi yang gemilang terhadap hasil dari pekerjaannya.

\section{Kontribusi Kecerdasan Emosional terhadap Kinerja Guru BK \\ Kecerdasan emosional}

merupakan dasar bagi lahirnya kecakapan emosi yang didapatkan individu dari hasil belajarnya dari dalam diri dan lingkungannya yang dapat menghasilkan kinerja yang menonjol dalam pekerjaannya. Suasana hati yang tidak terkontrol akan dapat membuat individu mudah larut sehingga akan berdampak kurang baik untuk kinerjanya. Untuk itu seorang guru BK dapat mengenal dan mengelola emosinya dan emosi orang lain agar dapat bekerja dengan semangat sehingga guru BK dapat sukses dalam bekerja. Sebagaimana yang disimpulkan Jurana (2017) bahwa semakin tinggi kecerdasan emosional maka semakin tinggi pula kinerja guru.

Kecerdasana emosional seseorang dapat dilihat dari indikator emosi yaitu Kemampuan individu untuk mengenal emosi, mengelola emosi, memotivasi diri, mengenal emosi orang lain dan membina hubungan. Seseorang yang mengenal emosinya dan dapat mengelola emosinya dapat memotivasi 
dirinya untuk dapat berinetraksi dan bekerja dengan baik. Semakin tinggi seseorang dapat mengenal dan mengelola emosinya semakin dapat individu tersebut mengatur suasana hatinya sehingga dapat beraktifitas dengan baik dan akan berdampak baik terhadap kinerjanya.

Seseorang yang memiliki kecerdasan emosi yang tinggi akan lebih percaya diri, lebih bahagia, populer, dan sukses di tempat ia bekerja. Mereka lebih mampu menguasai emosinya, dapat menjalin hubungan yang baik dengan orang lain, mampu mengelola stress dan memiliki kesehatan mental yang baik. Individu dengan kecerdasan emosi yang tinggi dipandang oleh pimpinan dan rekan kerjanya di tempat ia bekerja sebagai individu yang tekun dan disukai ditempat ia bekerja dan dimana ia berada.

\section{Kontribusi self efficacy dan Kecerdasan Emosional terhadap Kinerja Guru BK}

Kinerja guru dipengaruhi oleh beberapa faktor, antara lain adalah kepemimpinan kepala sekolah, motivasi kerja, kecerdasan emosional, tingkat pendidikan, Kompetensi guru, kedisiplinan, pengawasan, Pendidikan dan latihan. Dalam proses pelayanan, seorang guru akan dapat melaksanakan dengan baik apabila didukung oleh keyakinan diri (self efficacy) akan kemampuannya yang tinggi dan kecerdasan emosional yang stabil.

Seorang guru Bimbingan dan Konseling yang mempunyai keyakinan diri (self efficacy) terhadap kemampuannya yang tinggi akan bersemangat dalam melaksanakan tugasnya dan selalu berusaha untuk meningkatkan kemampuannya. Begitu juga dengan guru BK yang memiliki kecerdasan emosi yang tinggi dapat membantu guru lain yang mengalami kinerja rendah sehingga terbentuk suatu lingkungan yang mempunyai kinerja tinggi, yang secara tidak langsung akan kembali menguatkan kinerja guru BK.

Keberhasilan dari kinerja guru Bimbingan dan Konseling dapat dilihat dari Kualitas hasil kerja guru BK, kuantitas hasil kerjanya, Inisiatifnya dan kerja sama yang baik dengan lingkungan kerjanya. Semakin baik kualitas kerja guru bk dimana ia bersemangat dalam merancang program kegiatan layanan, melaksanakan layanan dan dapat mengevaluasi layanan maka semakin berkualitas kinerjanya. 


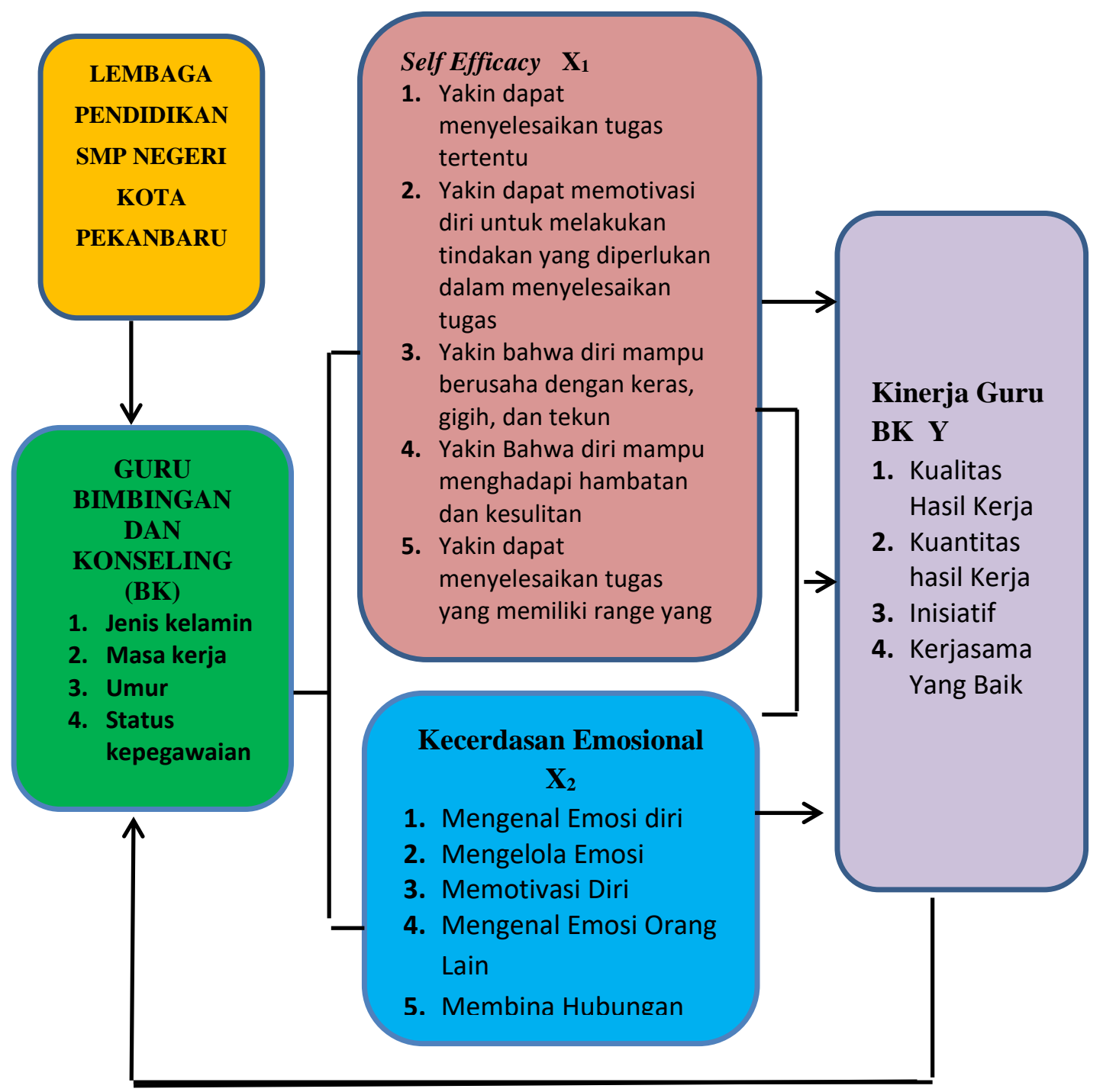

Gambar Kerangka Pemikiran Penelitian

\section{Hipotesis Penelitian}

Karena penelitian ini terdapat keterkaitan antar variabel khususnya Kontribusi antar variabel, maka hipotesis pada penelitian ini adalah:

1.Terdapat Kontribusi positif dan signifikan Self efficacy terhadap Kinerja Guru Bimbingan dan Konseling (BK) SMP Kota Pekanbaru.

2. Terdapat Kontribusi positif dan signifikan Kecerdasan emosional terhadap Kinerja Guru Bimbingan dan Konseling (BK) SMP Kota Pekanbaru.
3. Terdapat Kontribusi positif dan signifikan Self efficacy dan Kecerdasan Emosional secara simultan (bersama-sama) terhadap Kinerja Guru Bimbingan dan Konseling (BK) SMP Kota Pekanbaru.

\section{METODOLOGI PENELITIAN}

Objek dari penelitian ini adalah Self Efficacy, Kecerdasan emosional dan kinerja gru BK. 


\section{Populasi dan Sampel Penelitian}

Populasi dalam penelitian ini adalah Guru Bimbingan dan Konseling SMP kota Pekanbaru berjumlah 103 orang. Sedangkan sampel dalam penelitian ini berjumlah 82 orang guru BK SMP yang terdiri dari sekolah Negeri dan Swasta Kota Pekanbaru dengan taraf kesalahan 5\% dengan menggunakan rumus Isaac dan Michael.

Uji Coba Instrumen akan dilakukan terhadap 20 orang guru BK SMP Negeri dan Swasta Kota Pekanbaru.

Tabel Jumlah Guru Bimbingan dan Konseling (BK) SMP di Kota Pekanbaru yang menjadi populasi dan sampel penelitian

\begin{tabular}{|c|c|c|c|c|c|}
\hline \multirow[t]{2}{*}{$\begin{array}{l}\text { Status } \\
\text { SMP }\end{array}$} & \multirow[t]{2}{*}{$\begin{array}{l}\text { Popu } \\
\text { lasi }\end{array}$} & \multirow[t]{2}{*}{$\begin{array}{l}\text { Sa } \\
\text { mp } \\
\text { el } \\
\text { Pen } \\
\text { eliti } \\
\text { an }\end{array}$} & \multicolumn{2}{|c|}{\begin{tabular}{l}
\multicolumn{1}{c}{ Jenis } \\
Kelamin \\
Sampel \\
Penelitia \\
n
\end{tabular}} & \multirow[t]{2}{*}{$\begin{array}{l}\text { Sa } \\
\text { mp } \\
\text { el } \\
\text { Uji } \\
\text { Co } \\
\text { ba }\end{array}$} \\
\hline & & & $\mathrm{L}$ & $P$ & \\
\hline Negeri & 81 & 64 & 5 & 59 & 15 \\
\hline Swasta & 22 & 18 & 1 & 17 & 5 \\
\hline Jumlah & 103 & 82 & 6 & 76 & 20 \\
\hline
\end{tabular}

Sumber: Data Guru Pembelajar MGBK SMP Kota Pekanbaru

\section{Teknik Pengumpulan Data}

Pengumpulan data yang digunakan penulis adalah dengan menggunakan teknik Kuesioner atau daftar pertanyaan yang dibuat dalam bentuk sederhana dengan metode pertanyaan tertutup yang diberikan kepada pihak responden sehingga memperoleh data tentang self efficacy, kecerdasan emosional dan kinerja guru Bimbingan dan konseling. Pengumpulan data atau angket pada penelitian ini digunakan untuk mendapatkan data dan menggali data tentang sesuatu yang berkaitan dengan penelitian

\section{Teknik Analisis Data}

Teknik analisis data yang digunakan dalam penelitian ini adalah analisis statistik deskriptif dan analisis statistik inferensial. Pengolahan data untuk analisis statistik deskriptif dalam penelitian ini menggunakan program Microsoft Excel dan SPSS versi 23 for Windows. Analisis statistik deskriptif dilakukan untuk memaparkan data profil responden dalam bentuk mean dari hasil angket, berdasarkan demografi responden, variabel dan indikator. Analisis statistik deskriptif meliputi demografi responden yang terdiri dari jenis kelamin, umur, dan status kepegawaian.

\section{Uji Coba Instrumen}

Dalam penelitian ini instrumen yang digunakan adalah uji validitas dan uji reliabilitas. Uji validitas instrumen dilakukan untuk menunjukan keabsahan dari instrumen yang akan dipakai pada penelitian. Menurut Sugiyono (2019:175), validitas adalah Alat ukur yang digunakan untuk mendapatkan data (mengukur Instrumen) menunjukkan valid.

Hasil analisis data uji coba untuk variabel Self Efficacy $\left(\mathrm{X}_{1}\right)$ dengan jumlah responden uji coba sebanyak 20 orang diperoleh jumlah item yang valid sebanyak 41 dari 42 item yang diuji cobakan, sebanyak 1 item dinyatakan tidak valid. dibuang dan tidak digunakan dalam penelitian lapangan.

Hasil analisis data uji coba untuk variabel Kecerdasan Emosional $\left(\mathrm{X}_{2}\right)$ dengan jumlah responden uji coba sebanyak 20 orang diperoleh jumlah item yang valid sebanyak 50 dari 54 item yang diuji cobakan, sebanyak 4 item dinyatakan tidak valid dibuang dan 
tidak digunakan dalam penelitian lapangan.

\section{HASIL PENELITIAN DAN PEMBAHASAN

Analisis deskriptif Variabel \\ Penelitian \\ Kinerja Guru BK (Y)}

$\begin{array}{ccc}\text { Variabel } & \text { Keterangan } & \text { Hasil } \\ \text { Statistik }\end{array}$

Sumber: Data Olahan 2020

Dari data ini dapat diintrepestasikan bahwa data variabel Kinerja Guru BK SMP Kota Pekanbaru berdistribusi Normal. Hal ini dapat dilihat dari nilai mean, median dan modus yang hampir sama sehingga diasumsikan bahwa kurva yang terbentuk adalah kurva simetris, sedangkan nilai maximum adalah 92,26, dan nilai minimum adalah 82,44, dengan demikian nilai Kinerja Guru BK SMP Kota Pekanbaru termasuk dalam kategori tinggi

\section{Self Efficacy $\left(\mathrm{X}_{1}\right)$}

\begin{tabular}{ccc}
\hline Variabel & Keterangan & Hasil Statistik \\
\hline & $\mathrm{N}$ & 82 \\
& Mean & 3,22 \\
Self & Median & 3,22 \\
Efficacy & Mode & 3,22 \\
& Range & 1,32 \\
& Minimum & 2,63 \\
& Maximum & 3,95 \\
\hline
\end{tabular}

Sumber: Data Olahan 2020

Dari data ini dapat diintrepestasikan bahwa data variabel Self Efficacy berdistribusi Normal. Hal ini dapat dilihat dari nilai mean, median dan modus yang hampir sama sehingga diasumsikan bahwa kurva yang terbentuk adalah kurva simetris, sedangkan nilai maximum adalah 3,95 dan nilai minimum adalah 2,63 maka dengan demikian nilai Self Efficacy termasuk dalam kategori tinggi.

\section{Kecerdasan Emosional $\left(\mathbf{X}_{2}\right)$}

\begin{tabular}{ccc} 
Variabel & Keterangan & Hasil \\
& Statistik \\
\hline & Mean & 82 \\
Kinerja & Median & 2,75 \\
Guru BK & Mode & 3,80 \\
& Range & 2,14 \\
& Minimum & 1,84 \\
& Maximum & 3,98 \\
\hline
\end{tabular}

Sumber: Data Olahan 2020

Dari data ini dapat diintrepestasikan bahwa data variabel Kecerdasan Emosional berdistribusi Normal. Hal ini dapat dilihat dari nilai mean, median dan modus yang hampir sama sehingga diasumsikan bahwa kurva yang terbentuk adalah kurva simetris, sedangkan nilai maximum adalah 3,98 dan nilai minimum adalah 1,84 , dengan demikian nilai Kecerdasan Emosional termasuk dalam kategori tinggi.

\section{Pengujian Hipotesis}

Pengujian hipotesis dalam penelitian ini bertujuan untuk menguji tiga hipotesis yang telah dirumuskan:

1. Terdapat hubungan yang signifikan antara self efficacy $\left(\mathrm{X}_{1}\right)$ dengan kinerja guru $\mathrm{BK}(\mathrm{Y})$. Hubungan korelasi antara self efficacy $\left(\mathrm{X}_{1}\right)$ dengan kinerja guru BK (Y). Dengan $\mathrm{P}$ value/Sig yaitu $0.000 \quad(0,000<$ 0.05), sehingga dapat disimpulkan bahwa terdapat hubungan yang signifikan antara kedua variabel dan terdapat kontribusi positif antara self 
efficacy $\left(\mathrm{X}_{1}\right)$ terhadap kinerja guru BK (Y). $\quad$ Pada $R$ square $\left(\mathrm{r}^{2}\right)=$ 0,156 atau $15,60 \%$, artinya besar kontribusi variabel Self efficacy $\left(\mathrm{X}_{1}\right)$ terhadap kinerja guru BK (Y) di SMP kota Pekanbaru adalah 15,60 \% sedangkan sisanya sebesar $84,40 \%$ ditentukan oleh faktor lain yang tidak menjadi bagian dari penelitian ini.

2. Terdapat kontribusi positif dan signifikan antara kecerdasan emosional $\left(\mathrm{X}_{2}\right)$ terhadap kinerja guru BK (Y) SMP kota Pekanbaru. Sedangkan besaran kontribusi variabel kecerdasan emosional $\left(\mathrm{X}_{2}\right)$ terhadap kinerja guru BK (Y) diperoleh $R$ square $\left(\mathrm{r}^{2}\right)=0,174$ atau $17,40 \%$, artinya besar kontribusi variabel kecerdasan emosional terhadap Kinerja guru BK di SMP kota Pekanbaru adalah 17,40\%, sedangkan sisanya sebesar $82,60 \%$ ditentukan oleh faktor lain yang tidak menjadi bagian dari penelitian ini.

3. Terdapat kontribusi positif antara self efficacy dan kecerdasan emosional secara bersama-sama terhadap kinerja guru BK di SMP kota Pekanbaru. Sedangkan besarnya self efficacy $\left(\mathrm{X}_{1}\right)$ dan kecerdasan emosional $\left(\mathrm{X}_{2}\right)$ dengan kinerja guru BK (Y) yang dihitung dengan koefisien korelasi yang diperoleh dari korelasi pearson sebesar 0 , hal ini menunjukkan bahwa terdapat hubungan yang kuat antara self efficacy $\left(\mathrm{X}_{1}\right)$ dan kecerdasan emosional $\left(\mathrm{X}_{2}\right)$ secara bersama-sama terhadap kinerja guru BK (Y), dengan $\mathrm{P}$ value/sig sama dengan $0,000<0,05$, sehingga dapat disimpulkan bahwa terdapat hubungan yang signifikan antara kedua variabel.

\section{Pembahasan Hasil Penelitian}

\section{Kontribusi Self Efficacy terhadap Kinerja Guru BK}

Sebagaimana hasil penelitian ini diperoleh hubungan yang signifikan antara self efficacy ( $\left.\mathrm{X}_{1}\right)$ terhadap kinerja guru BK (Y) di SMP kota Pekanbaru, dan besar pengaruhnya $15,60 \%$ dengan tafsiran rendah, karena masih terdapat sebesar $84,40 \%$ ditentukan oleh faktor lain yang tidak menjadi bagian dari penelitian ini. kontribusi ini digambarkan oleh setiap kenaikan satu satuan pada variabel self efficacy $\left(\mathrm{X}_{1}\right)$ yang akan diikuti peningkatan terhadap kinerja guru BK (Y) sebesar 0,395 satu satuan. Temuan penelitian ini tidak jauh berbeda dengan penelitian yang dilakukan Venna Trilolita (2017), Rian Salangka dan Lucky Dutolong (2015) yang menyimpulkan seseorang dengan self efficacy yang tinggi pada dirinya, cenderung akan berhasil dalam menjalankan tugasnya sehingga hal tersebut akan meningkatkan kinerjanya, dan bagitu pula sebaliknya, seseorang yang memiliki self efficacy yang rendah akan memiliki kinerja yang rendah. Karena seseorang dengan self efficacy yang tinggi akan siap menghadapi hambatan dalam berbagai situasi, dan kesulitan akan berusaha dengan keras untuk mengatasi suatu dalam bekerja. Hal ini juga membuktikan bahwa setiap individu akan berani dan bertanggung jawab untuk melaksanakan berbagai macam tindakan, ketika individu tersebut merasa yakin akan segala keinginan yang ditujunya akan berhasil diraih begitu juga sebaliknya. 


\section{Kontribusi Kecerdasan Emosional terhadap Kinerja Guru BK}

Sebagaimana hasil penelitian ini didapatkan hubungan yang signifikan antara variabel keceerdasan emosional (X2) terhadap kinerja guru BK (Y) di SMP kota Pekanbaru, dan besar kontribusinya $17,40 \%$ dengan tafsiran rendah, karena masih terdapat sebesar $82,60 \%$ ditentukan oleh faktor lain yang tidak menjadi bagian dari penelitian ini. kontribusi ini digambarkan oleh setiap kenaikan satu satuan pada variabel kecerdasan emosional $\left(\mathrm{X}_{2}\right)$ diikuti dengan peningkatan kinerja guru BK (Y) sebesar 0,417 satuan. Temuan penelitian ini diperkuat oleh penelitian yang dilakukan oleh Jurana (2017) menyimpulkan bahwa terdapat hubungan antara kecerdasan emosional dengan kinerja guru. Nilai signifikansi pada variabel antara kecerdasan emosional $\left(\mathrm{X}_{2}\right)$ dengan kinerja guru adalah $\mathrm{p}<0,001$. lebih kecil dibandingkan taraf signifikansi yaitu 0,05. Dengan demikian dapat disimpulkan bahwa terdapat hubungan antara kecerdasan emosional $\left(\mathrm{X}_{2}\right)$ dengan kinerja guru BK (Y). Elin Karlina (2014) menemukan bahwa terdapat pengaruh positif dan sangat signifikan kecerdasan emosional $\left(\mathrm{X}_{2}\right)$ terhadap kinerja guru BK $(\mathrm{Y})$. Pengaruh positif yang dimaksud memiliki arti bahwa kecerdasan emosional yang baik akan diikuti dengan meningkatnya kinerja guru. Dari hasil analisis tersebut dalam melaksanakan tugasnya, hendaknya seorang guru memiliki kecerdasan emosional yang tinggi sehingga dapat menggunakan perasaannya secara optimal guna mengendalikan dirinya sendiri dan lingkungan sekitar. Seorang guru yang memiliki tingkat kecerdasan emosional yang tinggi maka ia akan memiliki kinerja yang tinggi pula, ataupun sebaliknya.

3. Kontribusi Self Efficacy dan Kecerdasan Emosional terhadap Kinerja Guru BK

Sebagaimana hasil dari penelitian ini yang menunjukkan adanya kontribusi yang signifikan antara variabel self efficacy $\left(\mathrm{X}_{1}\right)$ dan kecerdasan emosional $\left(\mathrm{X}_{2}\right)$ terhadap kinerja guru BK (Y) di SMP kota Pekanbaru, dan besar kontribusinya $19,80 \%$ dengan tafsiran rendah, karena masih terdapat sebesar $80,20 \%$ ditentukan oleh faktor lain yang tidak menjadi bagian dari penelitian ini. Kontribusi ini digambarkan oleh setiap kenaikan satu satuan pada self efficacy $\left(\mathrm{X}_{1}\right)$ diikuti dengan peningkatan kinerja guru BK (Y) sebesar 0,209 satu satuan dengan asumsi bahwa variabel kecerdasan emosional $\left(\mathrm{X}_{2}\right)$ tetap dan setiap kenaikan satu satuan pada kecerdasan emosional $\left(\mathrm{X}_{2}\right)$ diikuti dengan peningkatan kinerja guru BK (Y) sebesar 0,276 satu satuan dengan asumsi bahwa varaibel self efficacy $\left(\mathrm{X}_{1}\right)$ tetap. Hasil penelitian ini didukung oleh penelitian Timoreza Putri Indriyani (2013), Atifah Ridhawati (2016), dengan hasil yang ditemukan adalah, terdapat hubungan yang signifikan antara efikasi diri dengan kinerja guru ekonomi pada SMA Negeri di Jakarta Timur. Hal ini bermakna bahwa efikasi diri dapat mempengaruhi kinerja seseorang. Semakin tinggi efikasi diri yang dimiliki guru maka akan semakin meningkat pula kinerja guru tersebut. Oleh karena itu guru disarankan agar memiliki efikasi diri yang tinggi 
yang selalu tertanam dalam dirinya agar guru tersebut dapat mendidik siswanya untuk menuju kesuksesan di masa yang akan datang. Dan kecerdasan emosional berpengaruh positif dan signifikan terhadap kinerja. Semakin tinggi kecerdasan emosional yang dimiliki seseorang maka akan semakin tinggi pula kinerja seseorang. Individu yang memiliki tingkat emosional yang baik akan lebih mudah menyesuaikan dirinya dalam pergaulan sosial dan lingkungan sekitarnya.

\section{SIMPULAN}

1. Diperoleh kontribusi yang signifikan antara self efficacy $\left(\mathrm{X}_{1}\right)$ terhadap kinerja guru BK (Y) SMP Kota Pekanbaru dengan kontribusi sebesar $15,60 \%$ dengan tafsiran rendah, karena masih terdapat sebesar $84,40 \%$ ditentukan oleh faktor lain yang tidak menjadi bagian dari penelitian ini.

2. Diperoleh kontribusi yang signifikan antara variabel kecerdasan emosional $\left(\mathrm{X}_{2}\right)$ terhadap kinerja guru BK $(\mathrm{Y})$ SMP Kota Pekanbaru dengan kontribusi sebesar $17,40 \%$ dengan tafsiran rendah, karena masih terdapat sebesar $82,60 \%$ ditentukan oleh faktor lain yang tidak menjadi bagian dari penelitian ini.

3. Diperoleh kontribusi signifikan antara self efficacy $\left(\mathrm{X}_{1}\right)$ dan kecerdasan emosional $\left(\mathrm{X}_{2}\right)$ terhadap kinerja guru BK (Y) SMP Kota Pekanbaru dengan kontribusi 19,80\% dengan tafsiran rendah, karena masih terdapat sebesar $80,20 \%$ ditentukan oleh faktor lain yang tidak menjadi bagian dari penelitian ini. Kontribusi ini digambarkan oleh setiap kenaikan satu satuan pada variabel self efficacy $\left(\mathrm{X}_{1}\right)$ diikuti dengan peningkatan kinerja guru BK (Y) sebesar 0,209 satu satuan dengan asumsi bahwa variabel bebas lainnya tetap dan setiap kenaikan satu satuan pada kecerdasan emosional $\left(\mathrm{X}_{2}\right)$ diikuti dengan peningkatan kinerja guru $\mathrm{BK}$ (Y) sebesar 0,276 satu satuan dengan asumsi bahwa variabel bebas lainnya tetap. Hal ini bermakna bahwa, kinerja guru BK sangat dibutuhkan dalam melaksanakan tugas. Karena kinerja guru dianggap penting untuk keberhasilan sekolah yang dipengaruhi oleh self efficacy dan kecerdasan emosional guru. Kinerja guru merupakan salah satu unsur penting yang harus dimiliki seorang guru seperti: (1) kompetensi pedagogic, (2) kompetensi kepribadian, (3) kompetensi sosial dan (4) kompetensi professional.

\section{UCAPAN TERIMA KASIH}

Pada akhirnya, penulis menyadari bahwaartikel ini tidak akan selesai tanpa dukungan dari rekanrekan majelis guru SMP Negeri 21 Pekanbaru atas segala bantuan dan dukungan yang telah diberikan.

\section{DAFTAR PUSTAKA}

Abd. Madjid, 2016. Pengembangan Kinerja Guru Melalui Kompetensi, Komitmen dan Motivasi Kerja. Yogyakarta: Samudra Biru. Hlm 2.

Abd. Mukhid, 2009, Self-Efficacy (Perspektif Teori Kognitif Sosial dan Implikasinya terhadap Pendidikan) Jurnal Pendidikan Islam (Print ISSN1907672X;Online ISSN 2442-5494 DOI: http://doi.org/10.19105/tipi). 
Daeng Ayub Natuna. 2016. Kontribusi

Akuntabilitas Guru dalam

Pelaksanaan Pembelajaran

Terhadap Penerapan Nilai

Kewirausahaan di SMA Negeri

Tambang, Kabupaten Kampar.

Pekanbaru: Pascasarjana

Universitas Riau.

Daryanto dan Mohammad Farid, 2015.

Bimbingan dan Konseling:

Panduan Guru BK dan Guru

Umum. Yogyakarta, Gava Media, hlm 123.

Hanung Sudibyo., 2018, Faktor yang mempengaruhi kinerja guru bimbingan dan konseling dalam publikasi ilmiah di SMP kabupaten Pekalongan, Prosiding Seminar Nasional BK 2018, Manajemen kependidikan Pasca Sarjana UNS, Semarang.

Heri., 2019, Manajemen Kinerja, PT Grasindo, Jakarta.

Leni Oktavia, 2018, Pengaruh Supervisi Kepala Sekolah Dan Self Efficacy Terhadap Kinerja Guru Dengan Motivasi Sebagai Variabel Intevening Pada Smk Bina Karya 2 Karanganyar, Sekolah Tinggi Ilmu Ekonomi (STIE) Putra Bangsa, Solo 